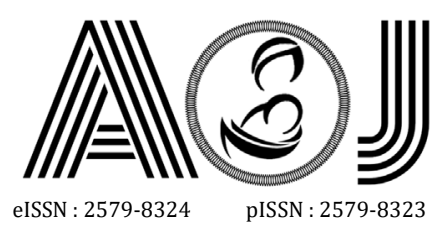

\title{
RESEARCH
}

\section{Reproductive Health Knowledge of Adolescent in Padang: Case Study of SMA N 1 Students}

\author{
Aladin \\ Affiliation author : Sub Division of Social Obstetrics and Gynecology, Obstetrics and Gynecology \\ Department, Faculty of Medicine, Andalas University, Dr. M. Djamil Central General Hospital Padang \\ Correspondence to: Aladin,email: aladin@med.unand.ac.id, Hp:081363829500
}

\begin{abstract}
The aim of this study is to describe the knowledge level and accuracy of reproductive health among students at SMA N 1 Padang. The study design was analytical survey with cross-sectional approach. The population were all SMA N 1 students while cluster random sampling was applied to get 267 students as respondents which represented each major (natural science or social science) and class (X, $X I$, and XII). The questionnaires were divided into several sections consisting the general knowledge of reproductive health, contraception, and sexually transmitted disease (STD). Result of the study showed that students in natural science major (scoring 71.9\%) were having better knowledge than students in social science major (scoring 51.8\%). It was also found that students in grade XII (scoring 67.7\%) were getting highest result compared to students in grade XI (scoring 61.4\%) and grade X (scoring 67.1\%). Nevertheless, the result was not satisfying, considering that the average score of all students were only 65.6\%. Therefore, guidance from parents, teachers, as well as counselling unit are crucial to help adolescent in Padang, in the context of reproductive health knowledge.
\end{abstract}

Keywords: adolescent, contraception, knowledge, reproductive health, sexually transmitted disease

\section{INTRODUCTION}

Adolescents are an important stage in reproductive health. ${ }^{1}$ Adolescence is a period of maturation of the human reproductive organs which is also called the transition period, where there are rapid physical changes and sometimes out of balance with mental development. This imbalance in mental development during the transition period can cause confusion among adolescents which could lead to irresponsible sexual behavior. ${ }^{2}$ One example is dating behavior that leads to premarital sex or free sex. The impact of this behavior includes the occurrence of teenage pregnancies, unwanted pregnancies and attempts to perform unsafe abortions. In addition, adolescents can get sexually transmitted diseases (STD) and face social impacts such as dropping out of school, community stigma and other social sanctions. ${ }^{3,4}$

Teens are looking for various sources of information that are easy to obtain, for example discussing it with peers, reading books or magazines about sex, accessing pornographic sites on the internet or experimenting with masturbation, even flirting or having sex with their partner. Lack of knowledge about reproductive health were causing many adolescents to 


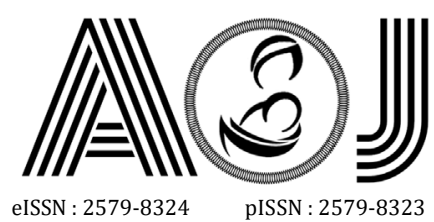

eISSN : 2579-8324
pISSN : 2579-8323

become victims of sexual crimes, such as rape, sex outside of marriage and pregnancy at a young age and put adolescents into other reproductive health issues, contacted with STD or being infected with HIV/AIDS. ${ }^{5}$

Education is one of the factors that has an important role in improving the quality of human resources and pursuing productivity in all sectors of life. The development of society today calls for the development of students who are carried out in a balanced manner, including: attitudes of knowledge, intelligence, and skills, the ability to communicate and interact with the wider community, as well as increase awareness of the environment. ${ }^{6}$

This study aims to measure adolescent knowledge on reproductive health, contraceptives, and sexually transmitted diseases. The case study taken is on students of SMAN 1 Padang. Several similar studies that have been conducted were in Sleman which measured knowledge about reproductive health of class $X$ students at SMK YPKK ${ }^{7}$ and perception regarding reproductive health of students at class VIII SMP Islam Sultan Agung 1 Semarang. ${ }^{8}$ Furthermore, similar studies also been done on students at Universitas Negeri Yogyakarta, ${ }^{9}$ and students at Universitas Sultan Ageng Tirtayasa ${ }^{10}$ to examine students perception on reproductive health.

\section{METHOD}

This study uses a mixed method, which combines qualitative and quantitative approaches in all stages of the research process. Mixed method is also referred to as a methodology that provides philosophical assumptions in showing directions or giving instructions on how to collect data and analyze data as well as a combination of quantitative and qualitative approaches through several phases of the research process. The mixed methods strategy used in this study was a sequence of quantitative and qualitative analyzes. The objective of this strategy is to identify concept components (sub-concepts) through quantitative data analysis and then collect qualitative data in order to expand the available information. ${ }^{11}$

Quantitative methods are used to find measurable information about students' knowledge of reproductive health and contraception, while qualitative methods are used to obtain information about students' opinion and perception about sexually transmitted diseases. The research was conducted at SMAN 1 Padang from September to November 2019. The population in this study were all students of SMAN 1 Padang consisting of class $X$ to class XII. The research sample was students of SMAN 1 Padang who were willing to take part in this research.

This study used the cluster random sampling method, by taking several members of the population as a sample from each class starting from class $X$ to class XII. The researcher gave a questionnaire to the sample group which contained questions regarding reproductive 


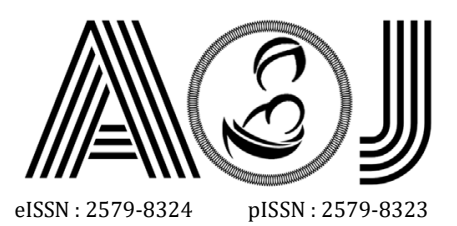

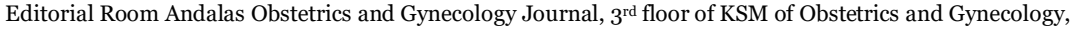

RSUP DR. M. Djamil Padang, Jl. Perintis Kemerdekaan Padang, Sumatera Barat 25127

health, contraception, and sexually transmitted disease. Sample size were determined using the following equation:

$$
n=\frac{N}{1+N e^{2}}
$$

where $n$ is sample size, $\mathrm{N}$ is the total population, and e is the error tolerance which is set as $5 \%$ margin of error. From the above equation, the sample size needed for this study is about 267 students.

Study procedures were as follows:

1. Collecting data on students who meet the inclusion criteria

2. Doing sampling using cluster random sampling method

3. Distributing questionnaires to collect data

4. Perform data processing and analysis

5. Present the data

\section{RESULT \& DISCUSSION}

\section{Sample characteristics}

From the total of 267 respondents, 85 students were in class $X, 83$ from class XI and 99 from class XII. Most of the students who filled out this survey were from natural science major (68.9\%) while students from social science major were only $31.1 \%$. Sample characteristics are shown in table 1 below.

Table 1. Sample characteristics

\begin{tabular}{lcc}
\hline \multicolumn{1}{c}{ Characteristics } & $\mathbf{n}$ & $\mathbf{\%}$ \\
\hline Class & & \\
$\mathbf{X}$ & 85 & 31.8 \\
$\mathbf{X I}$ & 83 & 31.1 \\
$\mathbf{X I I}$ & 99 & 37.1 \\
Major & & \\
$\quad$ Natural science & 184 & 68.9 \\
$\quad$ Social science & 83 & 31.1 \\
Gender & & \\
$\quad$ Male & 123 & 46.1 \\
$\quad$ Female & 144 & 53.9 \\
Monthly allowance (Rp) & & \\
$\quad<\mathbf{3 0 0 , 0 0 0}$ & 35 & 13.1 \\
$\mathbf{3 0 0 , 0 0 0 - 5 0 0 , 0 0 0}$ & 84 & 31.5 \\
$\mathbf{5 0 0 , 0 0 0 - 1 , 0 0 0 , 0 0 0}$ & 117 & 43.8 \\
$\mathbf{1 , 0 0 0 , 0 0 0 - 2 , 0 0 0 , 0 0 0}$ & 31 & 11.6 \\
\hline
\end{tabular}




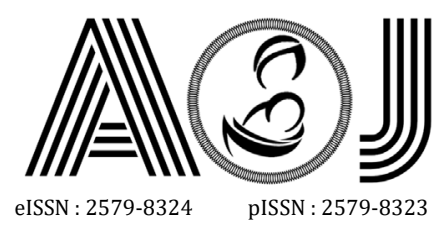

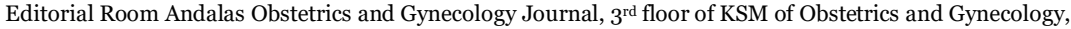
RSUP DR. M. Djamil Padang, Jl. Perintis Kemerdekaan Padang, Sumatera Barat 25127

\section{General Knowledge of Reproductive Health}

The questions prepared for the survey were covering several topics such as characteristics of sexual organs, sexual maturity, fertile time, pregnancy, and women readiness to become a mother. From all the questions, the most difficult question was about fertile time, of which only $40.8 \%$ students had the correct answers. The easiest question was related to pregnancy, where almost $95 \%$ students were correct.

Based on the survey result, it is found that students in natural science major were getting higher score $(71.9 \%)$ compared to students in social science major $(51.8 \%)$. This is obvious since students in natural science major were learning about reproductive health in biology subject. However, as biology subject were taught since junior high school level, those students should have higher score either they are in natural science major or in social science major. This finding indicates that students already forgotten biology subject that has been taught previously.

Comparing the results by class level, students from class XII were getting the highest score (67.7\%), as predicted. However, students from class XI were getting lower score $(61.4 \%)$ compared to class $X$ score (67.4\%). This issue needs further exploration on why students in class XI were not getting a higher score.

Looking into details in students from each class, there was a huge differences between results from students in natural science major and social science major. Class XII students in natural science major were having the highest score (76.5\%) while class XII students in social science major were getting the lowest score (49.2\%). Comparison of each class can be seen in Figure 1. 


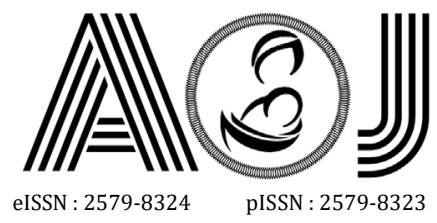
ANDALAS OBSTETRICS AND GYNECOLOGY JOURNAL Address for Correspondence:

Editorial Room Andalas Obstetrics and Gynecology Journal, $3^{\text {rd }}$ floor of KSM of Obstetrics and Gynecology, RSUP DR. M. Djamil Padang, Jl. Perintis Kemerdekaan Padang, Sumatera Barat 25127

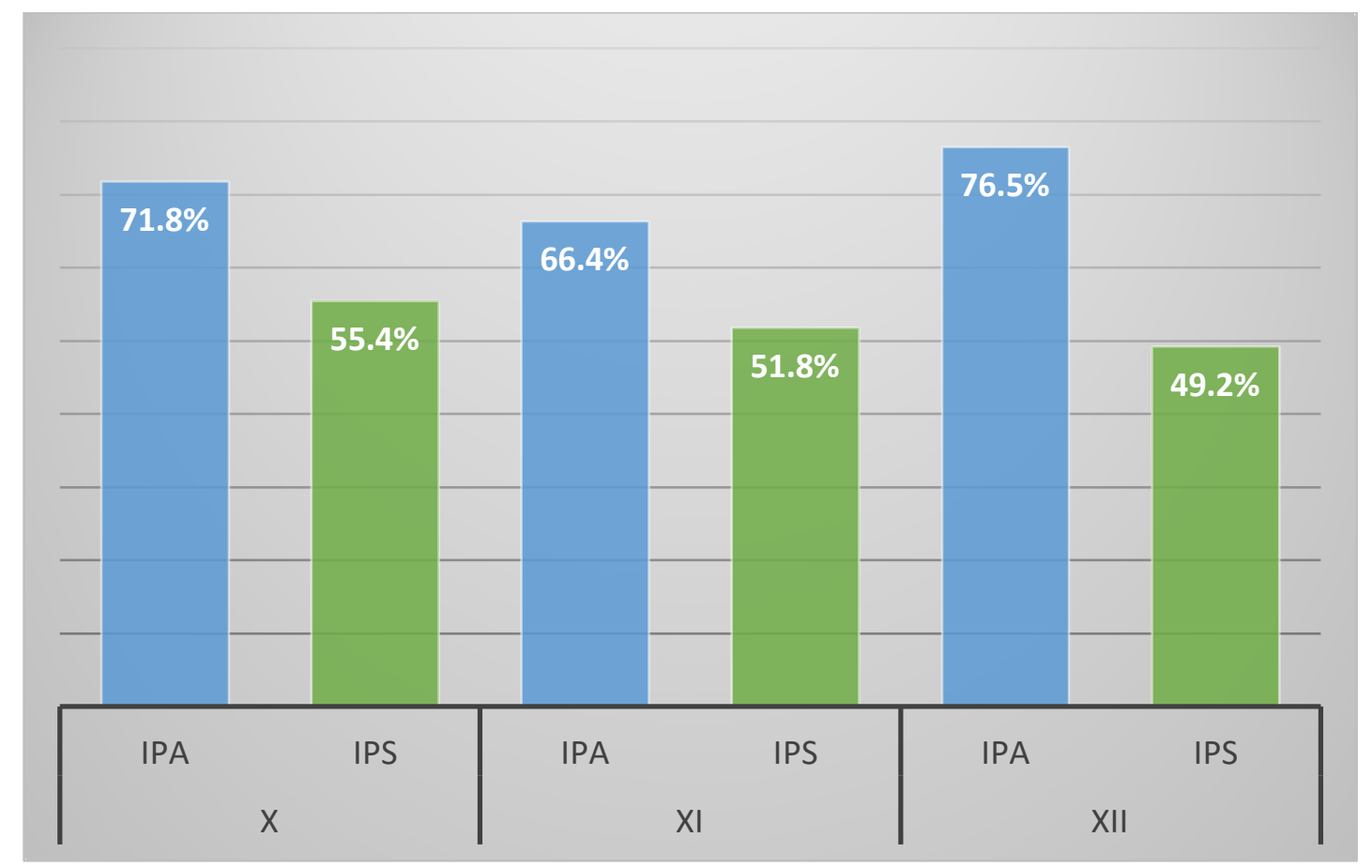

Figure 1. Students' knowledge score on reproductive health

\section{Contraception}

This study also assess students' knowledge on contraception, such as its function and examples. In average, SMAN 1 students were getting 89.9\% score. This score was distributed evenly in every class level and both natural science major and social science major. However, students in social science major were getting higher score $(92.8 \%)$ than students in natural science major (88.6\%). This indicate that knowledge of contraception were obtained mostly from outside school subject.

Details of each class score is shown in Figure 2. Students at class XI social science major were getting the highest score with $96.4 \%$, followed by students at class $X$ social science major with $95.7 \%$ score. On the contrary, students at class XI natural science major were having the lowest score with $83.6 \%$ score, followed by students at class XII social science major with 87.5\% score. Nevertheless, these score were much better than previous category on reproductive health. 


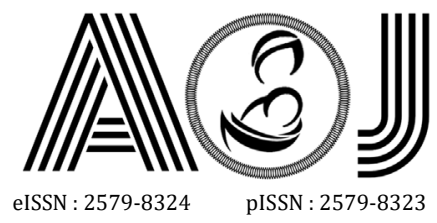
ANDALAS OBSTETRICS AND GYNECOLOGY JOURNAL Address for Correspondence:

Editorial Room Andalas Obstetrics and Gynecology Journal, $3^{\text {rd }}$ floor of KSM of Obstetrics and Gynecology, RSUP DR. M. Djamil Padang, Jl. Perintis Kemerdekaan Padang, Sumatera Barat 25127

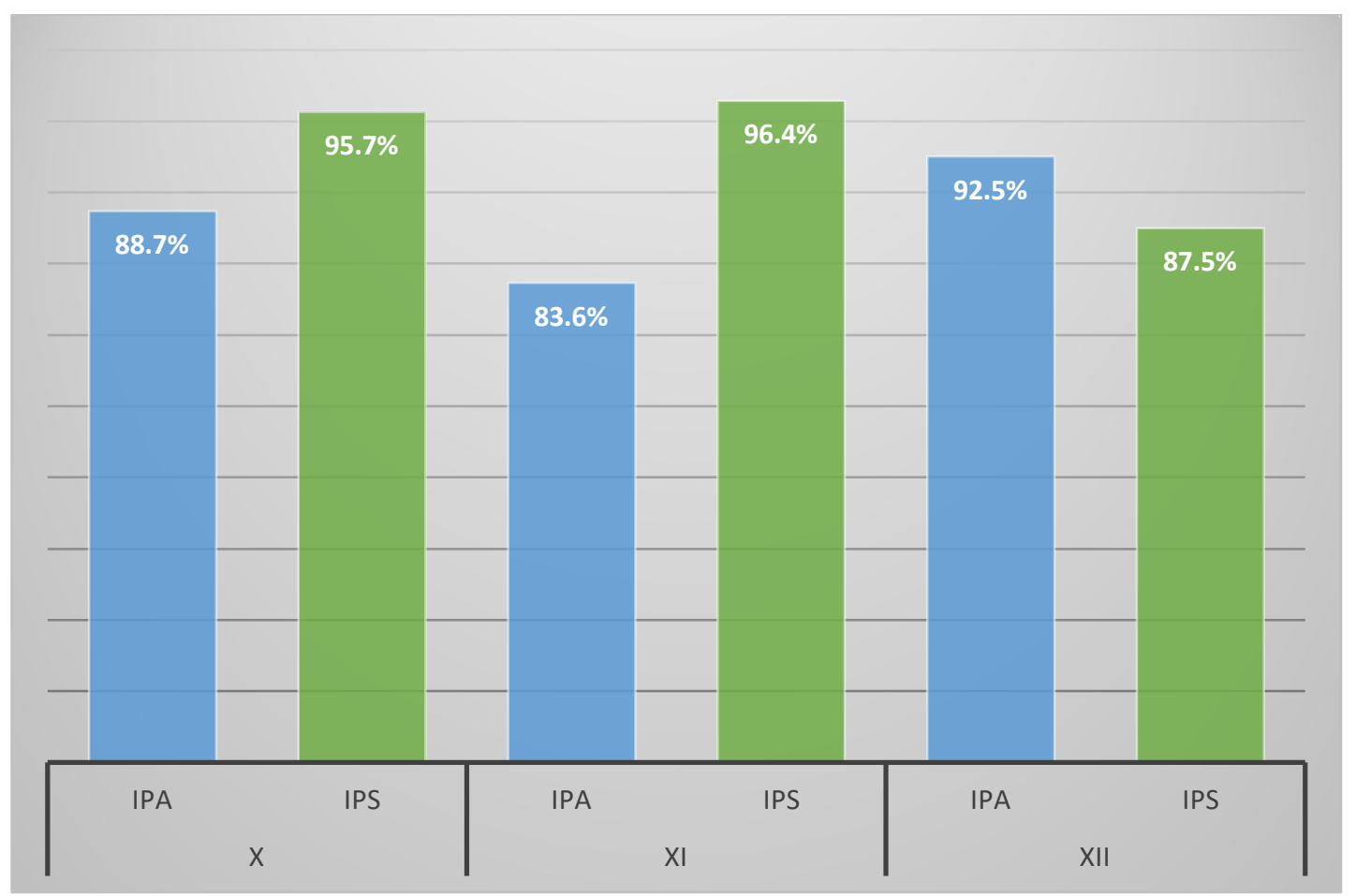

Figure 2. Students' knowledge score on contraception

\section{Sexually Transmitted Disease}

Most of SMAN 1 Padang students already knew about sexually transmitted disease (STD), such as syphilis and gonorrhea. They also knew about how those disease could be transmitted to other people, including how HIV/AIDS could be transmitted. From 267 students, only 17 students answered either wrongly or they did not know how STD are transmitted. This was a very good result, since knowledge on STD was not only taught at class but also disseminated through social media, television, and other information in many public places.

\section{CONCLUSION}

Students at SMAN 1 Padang were having quite low knowledge on reproductive health (average score 65.6\%). Most students already understand about sexual organ and pregnancy since those were taught in class even since junior high school, but mostly did not know about fertile time and women readiness to become a mother. Most students also understood about the function and examples of contraception (average score $89.9 \%$ ) as well as about sexually transmitted disease (average score 93.6\%). From these results it is arguable that students' knowledge on reproductive health, contraception, and STD were mostly obtain from outside school, therefore parents and teachers guidance were crucial to help students getting a comprehensive knowledge. 


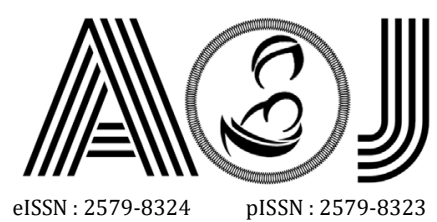

eISSN : 2579-8324
pISSN : 2579-8323

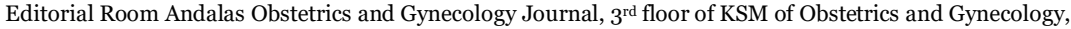

RSUP DR. M. Djamil Padang, Jl. Perintis Kemerdekaan Padang, Sumatera Barat 25127

Website:

http://jurnalobgin.fk.unand.ac.id/index.php/JOE

\section{REFERENCES}

1. Badan Kependudukan dan Keluarga Berencana Nasional (BKKBN), Badan Pusat Statistik (BPS), Kementerian Kesehatan (Kemekes), ICF International. Survei Demografi dan Kesehatan Indonesia 2017: Buku Remaja. Jakarta; 2018.

2. Lestary $\mathrm{H}$, Sugiharti. Perilaku berisiko remaja di indonesia menurut survey kesehatan reproduksi remaja indonesia (SKRRI) tahun 2007. J Kesehat Reproduksi. 2011;1(3):13644.

3. Suratno YRL. Deskripsi Perilaku Pacaran Sehat di Kalangan Siswa-Siswi Kelas XI SMA Negeri 1 Baturetno Tahun Ajaran 2014/2015 dan Implikasinya Terhadap Usulan TopikTopik Layanan Bimbingan Pribadi Sosial. Universitas Sanata Dharma; 2016.

4. Aini AN, Elliana D. Studi diskriptif tentang gaya pacaran siswa SMA Kota Semarang. Din Kebidanan. 2012;2(1):1-10.

5. Arsyadani R. Perbandingan persepsi Mahasiswa lulusan Berbasis Umum dan Agama tentang Perilaku seks Pranikah Di lingkungan sekitar Universitas Muhammadiyah Surakarta. Universitas Muhammadiyah Surakarta; 2010.

6. Halima, Raman R. Persepsi Remaja Tentang Kesehatan Reproduksi Di Pondok Pesantren Manahilil Ulum Hidayiah Kaballangan Kabupaten Pinrang. J Kesehat Masy. 2014;

7. Zullaika IN. Faktor-faktor yang Berhubungan dengan Persepsi Remaja Putri tentang Kesehatan Reproduksi Remaja di SMK YPKK 3 SLEMAN. Sekolah Tinggi Ilmu Kesehatan 'Aisyiyah Yogyakarta; 2015.

8. Rianda OR, Saraswati S. Persepsi Siswa Kelas VIII tentang Kesehatan Reproduksi Remaja dan Penyakit Menular Seksual. Indones J Guid Couns Theory Appl. 2015;

9. Pertiwi KR, Salirawati D. Pengetahuan dan Persepsi Mahasiswa tentang Kesehatan Reproduksi dan Permasalahannya. J Penelit Hum. 2014;19(2):104-15.

10. Ratnasari D, Rifqiawati I, Wahyuni I, Sari IJ, Syauqiah SG. Persepsi Mahasiswi Untirta terhadap Kesehatan Reproduksi dan Permasalahannya. Biodidaktika J Biol dan Pembelajarannya. 2020;15(1):1-5.

11. Sugiyono. Metode Penelitian dan Pengembangan. Bandung: Alfabeta; 2016. 